\title{
Enhancing African Development through Freedom: An Assessment of Dukor's Philosophical Basis of African Freedom
}

\author{
Chuka A. Okoye \\ Department of Philosophy, University of Nigeria, Nsukka, Nigeria \\ Email: chukeeye@yahoo.com
}

Received October $5^{\text {th }}, 2012$; revised November $7^{\text {th }}, 2012$; accepted November $20^{\text {th }}, 2012$

\begin{abstract}
The African continent has long suffered serious developmental relapse in a continually developing world. Lots of thinkers indeed term most of these African states "failed states". One sees that that while many other nations of the world develop and as such interact conveniently in this global village, most African nations come merely as beggars in the global village having nothing to offer but begging for an opportunity for consumption. These nations therefore remain stagnated and continually retrogressive in all aspects of human life. Where in lies the cause of these problems? Dukor opines that the problem is a re-echoing aftermath of the western deplorable actions against these Africans. Indeed Dukor concludes that there is no real honesty in the opportunities all member states have to take part in the process of global development. Africa seems to be cheated. This work does not seem to fully agree with Dukor that the western hegemony ALONE is the cause. This work submits that the complacency of most Africans equally play the role in their underdevelopment.
\end{abstract}

Keywords: Africa; Philosophy; Development; Freedom; Dukor

\section{Introduction}

The Most Important aspect of the human existence, disputable though, lies in development. Development involves transcendence from one level of life to another. This is a stage by stage evolution of a more advanced and sophisticated personality. It is sequel to this very important aspect of the human life that globalization comes in as a system of advancing integral development among nations. Invariably, globalization operates theoretically on the platform of global interrelationship. This interrelationship consists in tracks, politics, economy, communication, industrial exchange and religion.

It is therefore important, at this juncture, to note that the grounds of every globally based development on intercultural dialogue and cultural exchanges. The interaction among cultures makes it important to establish systematic equality in the process of human development among the various cultures in the world. This human development centers in development through freedom. Genuine development is grounded on freedom marked by an ingenious ability to synthesize various actions and events in the universe. Freedom here amounts to "choice between many or at least more than just alternatives; this particularly means a valuable freedom ... the importance of free-will comes out in this condition when one makes a choices with the full concept of the will (Swineburne, 2003: p. 107).

Swineburne, above, stresses on what the element of freedom consists in. Apparently, freedom begins with a psychological freedom wherein an individual has an independent thought. It, equally, encapsulates a physical and metaphysical freedom where an individual is not enslaved by "the other" even in their own freedom. The above captures the African predicament in their race towards development. The Africans, while they per- sistently work towards development in the supposed freedom, constantly lag behind in their quest to join other continents in their race towards development. Globalization, by its terms, spells justice for all and a revelation of a guide for the perplexed. However, the practice of globalization seems to be devoid of what its theories are.

Africa has suffered over the years from retrogression. This retrogression is blamed primarily on the Africa experience through the western domination of Africa, and secondly on the system of the African worldview which appears stereotype. These reasons for African retrogression call for real emancipation of the African from both psychological and physical slavery to freedom for more proper development. This is the idea Dukor presents in the series of his work on "African freedom and the philosophical freedom". This work thus attempts at making analysis of Dukor's philosophical basis of African freedom with a view to seeing how this can enhance African development in the globalizing world.

\section{African and the Negative Freedom}

The problem of the African system is primarily identified as problem of identity. The problem lies in the crises which the African has of his values: what is right or what is wrong, who he is and/or what he stands for. Apparently the African experience comes from divergent processes of assimilating their existence. One finds it hard to really place the core African value system. The only system left for examination among Africans are those left by the "west" and the yard stick left by them equally to measure them. This amounts to cultural ambiguity which according to William Abraham (1962: p. 35), is characteristically accompanied by misgivings of wide-ranging propor- 
tions.

The enslavement of African psychology set the stage for the down casting of the African development process. This showcases "negative freedom" among Africans. The choice of the clause "negative freedom" is apt since the Africans claim to be free by their cosmological finding whereas metaphysically, physical and psychologically, Africa lies in the annals of slavery with very slim hope of rising. This African negative freedom comes as a result of the African experiences over the years and the negative view given the Africans over the years.

The slave trade, in the first place, dealt a terrible blow on the psychology of the Africans and further negatively influenced the global perception of the African.

The slave trade led to sociopolitical disintegration and distortion, to economic stagnation and decline, and to mental or intellectual atrophy (Afigbo, 1993: p. 10).

Indeed Mokwugo decried the situation of the Africa and the slave trade. Picturing it as a "gory story of inhumanity and indignity meted out to the African, not for any crime committed but in pursuit of wealth (1964: p. 97). Colonialism, on the other hand, has systematically eaten deep into the African system. Thus while condemning what is left of the traditional African value system; the west imported their strange culture into the African system. This renders the African system dysfunctional. Indeed there is a conscious alienation of the African from himself through education which consistently denigrates the tenets of the African traditional system. Thus the more one is educated the more "unAfrican" one becomes.

Rodney occludes, in line with this, that among the most educated Africans were to be found the most alienated. Thus to the extent that they were Europeanized, to that same extent were they deAfricanized (1972: pp. 264,273).

The negative freedom thus keeps Africa stagnant in the guise that the African value system is either faulty fetish, outlandish, or even a savage. The real development and existential maturity comes when westernization is enthroned and followed. Indeed anything African is yet to develop and thus should be kept aside from the frontier of development at length Janheinz Jahn (1961: p. 20) typically asserts

[That] Only the most highly cultivated person human, cosmopolitan, enlightened; progressive counts as a real European. A real African, on the other hand, lives in the bush, craves "primitive" sculpture, can neither read nor write, goes naked...) the more primitive, the more really African.

Jahn represents the negativity of the African situation. His logical deductive analysis of the African as " $[\mathrm{X}$ is $\mathrm{X}]$ and always X" does not seem to give the African any chance of development. Nevertheless, the picture he paints is descriptive of the scenario which brings Africato her knees psychologically. The contemporary African aims at being perfect. And since perfection means being European, an African becomes European in his life and character while yet becoming African in his nomenclature. The African is therefore neither here nor there. The situation is replicated in Killens' Explanation of the Black Psyche while referring to a system of insecurity that bedevils the Afro-American. This is about the utter heart break of the Mulatto who rejected his black blood and was in turn rejected by his white blood (1968: p. 138).
The African sees nothing wrong with westernization no matter how bad any aspect of it appears. In fact, it is indeed a great event of change and blessing that the fore Africans were enslaved and colonized. This attitude negatively deals with the Africans in pursuit of development and freedom. The African professes freedom yet is structurally, politically, morally and cultural enslaved. What is therefore construed as development goes along this line of slavery. It is therefore impossible to achieve any kind of positive independent development without an enslaving dependence on the west that has given her (Africa) the identity she has.

Development, which according to Eastern is a self-realization within the context of society and successful international interaction (1960: p. 38), seems to have by-passed Africa since there is neither self realization nor any independent successful international interaction. African solely depends on the sour fruits of western hegemony running round the same plane and playing the same dishonest politics of retrogression. This picture is clearly painted by Maduabuchi Dukor thus:

Because of the philosophy of domination and superiority complex created by the enlightenment period and the subsequent emergence of "I" and "centre" ontologies, the Europeans embarked on the scramble for the colonization and partitioning of Africa, their supposedly interior (...). The tentacles of colonialism included the universalization of European culture, psychic and political domination and economic exploitation (2010: p. 151).

It is therefore, not very strange to say that the system of globalization in which Africa is a negative participant leaves African several years behind others in the stream of development. The problem here is not that Africa has been robbed or is terribly enslaved. The problem is that Africans seem to be ignorant of the depth of effect of this enslavement. It is paramount that the African mind is decolonized in order to see clearly the destructive effect of the enslavement which the African calls freedom. This is negative freedom.

The first aspect of this negative freedom lies in the indoctrination of the African who seems to see every aspect of development as being European. Thus the white race stands out just like Hume postulates

There never warn a civilized nation of any other complexion than white, nor warn any individual eminent either in action or speculation. No ingenious manufacturer among them, no arts no sciences [...] such uniform and constant differences could not happen ... if nature had not made an original distinction between these breeds of men (2010: p. 73).

Hume's explanation depicts a summary dismissal of the African race as lower humans while extolling the white race. This psychological implantation informs the mind of the African. Thus the whites are gods, blacks ... are merely lower human. This primary aspect of psychological indoctrination is not as bad, in the final analysis, as the psychological disillusionment which is a second aspect of this negative freedom.

In this second aspect, the Africans are psychological bound in accepting the status quo. "Africa is down and can never rise." This disillusionment breaks every effort made by Africans to rise and even dampens the will of the Africans to strive for their freedom and development. There is a tendency to 
count the damages of the past as the main reason for the negative of the future. The tendency here is that the seeming achievement of the very remote past are re-echoed and projected and the cause of the damages of the present blamed solely on the west but with little effort and will to rise.

Sequel to the above, one sees in the contemporary African philosophical thinking a steady effort to prove existence of African philosophy only as a collection of values which has been so damaged by colonialism. The African philosophical polemics does not end the instances. Archaeological finding which depict a sophisticated black culture from the 8th century B.C to the middle ages (see Onyeocha 1997: p. 52) and which has been damaged by colonialism serves another instance. But what positive effect does this have on the African development becomes a question open ended. Indeed Franz fanon cites this and warns for redirection thus:

I am convinced that it would be of greatest interest to be able to have contact with a Negro literature or architecture of the third century before Christ. I should be very happy to know that a correspondence had flourished between some Negro Philosopher and Plato. But I can absolutely not see how this fact would change anything ... (1964: p. 119).

Fanon calls for a total change from the complacency of the African mind in negative freedom. Every thought must therefore be marshaled by an affirmative action which drifts gradually to the knowledge that the so tangibly held negative freedom is indeed psychological slavery. African system therefore has been found in the depth of negative freedom which draws her away from authentic freedom. The effect comes out in the permissive neocolonialism which suffuses the African international relationship with others in the world.

\section{In Search of True African Freedom: Dukor's Idea}

The primary step to the designation of true path to African freedom lies in the basic understanding of the humanness of the African. There is an ontological equality which underlies the whole human system. So long as the human being is human, he is free. Dukor corroborates this through a logical analysis of the ontological humanness of every human being.

The humanity of man is empirically and biologically and intuitively cognitive it is a logical and necessary with whose opposite is a contradiction the humanity of aces can be expressed logically to mean that every race $\mathrm{X}$ has a human origin $\mathrm{H}$ or alternatively put, every man is man [...] (x) $(\mathrm{Rx} \supset \mathrm{Hx})$ or (x) (Mx כ.Mx) ... (2010: p. 95).

Dukor's contention here is that the freedom of man is really ontological to the human's existence. Thus every human being is born equal to the other. This cancels out the claims of slavery and the racist incarceration which tends to see some races as superior and other as inferior. The primary circumstance of the African existence underscores the fact that the African is ontologically equal to the Westerner and at the same time given to the same freedom which is possessed by the white. As such the conceptualization of the African system as poor and inferior does not represent a strong stance upon which the development stride of the African can commence.

The positive freedom which Dukor advocates is equally proved from the teleological string. By creation and nature, theology asserts human freedom. By creation man is believed to recreate himself and his environment. The view which Dukor brings forward lies in the human auto transcendence. Man, as auto-transcendent, is historically and analytically structured for development of his universe. Indeed the idea of temporality given to man by his fact of being created by God is fully demonstrated by Heidegger while analyzing the human existential character in Dasein analytic.

Historicality as that, which determines Dasein, makes history possible. Historicality stands for the state of being that is constitutive for Dasein's historizing as such; only on the basic of Dasein historizing is anything like world history possible or can anything belong historically to world-history (1962: p. 67).

Historicality of man is fully expressed in the effort man makes as a being of possibility to go beyond himself in the life of presence and project into the future indeed Heidegger thinks that Dasein (man) ${ }^{1}$ tries always to transcend itself by projecting itself always towards the future and going beyond what is not (1962: p. 66). There is subtle realization that since humans create the world and sustain it by reason, it beholds on man to assert his freedom through his actions and assert the freedom of others by their interaction with them. This is given to man by God who answers the basic question of human freedom by the gift of freewill and faith.

Freewill and faith are gifts of God which are cultivated through reflection on the ethical or existential aspects of religion (a congregational worship of God) "rather a narrow metaphysical acquisition of same". Dukor finds a clearer teleological description of the human positive freedom and indeed the African freedom in particular, in liberation theology.

In liberation theology, God answers the question concerning African freedom [...] liberation theology in this context seeks to free the downtrodden, the African from the Westernized and neo-colonized theology views man as a historical subject capable of making himself as well as his reflection and cultures ... it is therefore, a reflection on the ethical, or existential aspect of all religions rather than of its narrow metaphysical dimension (2010: p. 97).

The religious grounds of the African existence give the African freewill to the choice of faith. It is in this faith-utter trust in the love of God (Dukor, 2010: p. 97) - that "God should answer to the question of African freedom and authentic existence of freedom" which lies in human faith in God: Dukor's idea of the teleological proof of the African freedom basically lies in the meta-logical systematization of the teleological history. This is built on faith and the grounds of freewill following the concrete interaction between Christianity and the ground ethical structure of the African identified as "African pansychism"2.

In the final analysis, man as a being within history is determined by his self transcendence. It is in this self transcendence that man becomes a creator of the world and is determined in

\footnotetext{
${ }^{1}$ Heidegger's datum analysis does not explicitly call Dasein by the name "man" but the implications and the existential analysis of Dasein shows an existential analysis of man himself. See B \& T 28.

${ }^{2}$ African pansychism as Dukor puts it, is the belief of everything in the universe is spiritual and that spirits, divinities, plants, animals, physical objects, rivers and waters are creatures of God the supreme being.
} 
the love of God through faith which is found in the African pansychism. Dukor thinks that,

Africa is identified as part of the whole universe neither inferior nor superior to it. God is also viewed as a Redeemer and Emancipator; Africans should naturally not be slaves to any people or nation. Faith as the existence of freedom is the effect of God's grace because it is the action of God's love that is the necessary condition of the possibility of faith ... (2010: p. 98).

This teleological proof, despite its Christian appearance makes it cleverly valid. The introduction of faith and the creative role of man in the world lead to the nick proof of African freedom through self consciousness. Self consciousness represents a great drive to a human assertiveness and attempt to conquer the universe. It is in self assertiveness that the world is constantly created. Dukor insists that self-consciousness provides a good ground for freedom. Apparently,

Self-consciousness simply means self-awareness; it is the awareness of one's own mind and it acts and states. Selfconsciousness as a form of freedom presupposes the colligatory concepts of freedom; self perfection, self-determination and self-realization [...] the most fundamental and strongest impulse in man is the urge of instinct and urge of self for greater ideals ... the urge of self for greater ideals is the progress of self-consciousness (2010: p. 98).

Dukor took an existentialist stance in proposing African freedom through self consciousness though he implicitly believes that essence precedes existence. His assertion that existentialism amounts to untamed freedom underscores this point. Nevertheless, the idea of existentialism about freedom in relation to self consciousness brings out the need for human effort in achieving freedom Sartre indeed insists that

Man who involves himself and who realizes that he is not only the person he chooses to be but also a law maker who is at the same time choosing all mankind as well as himself cannot help escape the feeling of [...] deep responsibility ... man is condemned to freedom (1968: p. 20).

By the human choice, man is conscious of his existence in this consciousness, man asserts himself and determines his life and becomes a "lawmaker" who chooses both himself and other human beings. "Man is the future of man" (1947: p. 19). This entails that man is free from any form of slavery. Sartre indeed is deaf to any excuse for lack of freedom. In the Nausea he describes redundancy in slavery as universal negative to human nature. Apparently it is bad faith. Stumpf summarizing the task of Sartre on freedom states that.

Sartre explains the issue of freedom with consciousness. The activity of the consciousness is at this point two fold. First, consciousness defines specific things with world and invests them with meaning. Secondly, consciousness transcends, that is, puts a distance between yourself and object and in that way, attains freedom ...

Freedom lies in the consciousness of oneself. It connotes living above slavery; an individual's conscious effort to be free since man is seem to be always about his choices. Dukor buys into the tenets of existentialism, at this juncture. He links the African predicament with Sartre's "bad-faith". Africans for
Dukor "are said to be in bad-faith" if they cannot interpret their lives existentially free of any moral maxim or principle ... Africa should be a historical subject in the process of self creation (2010: p. 100). Apparently, the existential process leaves a lot in the hands of the Africans who are now not to dwell on the evils of the past meted on it by West but to rise up to self actualization. This is what this work projects in the second section about negative freedom. Dukor corroborates this in his statement that African political, economic and social unfreedom is her own making since she should have proved her freedom from the onset. He occludes:

Existentialism, espouses self-creation process as must liberation theology and African theistic pansychism. So, African freedom must mean her ability to emancipate herself from western domination politically, philosophically, economically and technologically through self-creative process. It means African capacity for self-determination and self realization (2010: p. 100).

The above creates a new process of inquiry into the African problem. The issue lies in the systematic restructuring of the African attitude to development. African backwardness is no longer directly on external repression of the growth process but a complacent under categorization of the will to develop by the Africans themselves. There is need for a pluralistic affirmation of the will to advance and genuine erasing of the psycho-social stigma which has held the Africans down. This will lead to a positive attitude towards development by an attempt to enhance an integrated growth through freedom.

\section{Africa and the Path to Development}

The structure of the African system is ontologically theistic. The theistic structure of the African system is seen in the African Conception of the universe. Indeed there is a serious trace of systematic pantheism. This systematic pantheism makes it possible for Africans to see God in everything and every event. Following this primary analysis Dukor chooses for the African System "Polymonothesism" which he thinks depicts the structure of the African system. Of course, the theistic approach of the African System encapsulates the pragmatic approach of the average African to issues and events.

The Africans asserts the potency and workability of his environment by the result it gives. While positive results show an entirety of well-being around the whole existential forces, negative results show that something has gone wrong in the chain of connection among the existential forces. Indeed, in as much as the African sees God in every aspect of life, there is a tendency ontological in the structure of African culture to manipulate the order of nature and the world entirely. Even though God is not challenged for certain negative occurrences, the intermediaries and the ancestors are often blamed and revolted against in such unpalatable event. As such one can hear among the Africans: If a deity proves stubborn we will show it the tree from which it is made.

The pragmatic structure of the African system is quickly demonstrated by Dukor who, in espousing the African polymonotheistic idea, emphasized that the spiritualist and idealistic belief in God and gods or ancestors is limited by their pragmatic and materialistic orientation in life ... while the gods, spirits and ancestors are asked to come and eat drink and to continue to protect them ... these gods and ancestors are ad- 
monished when they fail to live up to people's expectations (2010: p. 103).

This African attributes show that at the basis of the human existence, following the African system, there is an internal push to freedom. This push to freedom is informed by the value attached to the life of the African. Dukor surmises that the collective and individual basis of African freedom lies in God, self-consciousness and materialism. It is following these bases of African freedom that a new way will have to be charted for the African development.

Development seems to have happened on the Africans. While other people welcomed development with gusto, Africa seems to be engaged in an internal conflict between her current situation and the demands for development. There is a seeming entanglement in the African system which partly depends on their worldview, their system and to a great extent on the external denigration of the African continent.

On the part of the Africans, their cultural system seems to have been watered down by a "culture mix". This leaves them redundant and heavy to rise like the rest. What constitutes life is consumerism, which often drags the continent into the dragnet of corruption. There is a large dependence of the Africans on the west for everything including environmental structuralization. There is an apparent mediocrity which greets the Africans dwelling in the continent. This calls for a psychological cleanse. There is need for total de-ideologization of the African mind. The Africans needs to be raised from the doldrums of laxity and lassitude which has really led to their total dependence. It begins with a "ratiocinative deconstruction".

Here, the African must reason out processes of pulling down the walls of negative attitude preponderant in the African system. This lassitude however is not independent of the colonial impact. The colonial impact dealt with Africans psychology and left a trauma that appears to have dwarfed the ingenuity of the Africans. Dukor acknowledges it and calls for a world of pluralism devoid of every kind of racism but ensures freedom for all. Dukor believes that Africa ought to have exceeded this level of perpetual infancy in this continual pressure of western domination were not upheld. With pluralism, the world would have been more balances and successful indeed Dukor says.

Pluralism as a philosophical concept and doctrine is rooted in the realm of ideas whose elaboration in practice has been found to be of practical importance to humanity. In practice and theory, it tends to reconcile the divergent and conflicting views and values of life. Pluralism, analytically and philosophically makes nonsense the distinction among cultures, religion, races and colors (2010: $p$. 104).

The best bait on the African development in the relative to pluralism postulated by Dukor is re-echoed by Jurgen Habermas who believes that,

[...] we humans learn from one another... this image of man's position in the world expresses the intuitive sense of the deep-rooted reciprocal dependence of one person on the other ... (2004: p. 243).

Since the human interdependence makes for a better world the need for segregation drops. This is the call there in globalization. Globalization makes it open for everyone, race, nation to interact meaningfully and thus contribute by their various life-world or lived experiences to the global integral development. This is clearly demonstrated by Habermas.

The concept of society has to be linked to a concept of life world that is complementary to the concept of communicative action then communicative action becomes interesting primarily as a principle of socialization (Vergesells's Chafting): Communicative action provides the medium for this reproductive of life worlds. At the same time, processes of societal naturalization are given a different place. They transpire more in implicity known structures of the lifeworld than in explicity known action orientations (2004: p. 337).

The above corroborates what Dukor is arguing for; a world free from racism and inequality, a world of equal opportunity and independence. A world viewed from a universalistic perspective not just an anthropological downgrading.

On the other hand, the African system needs to be cleansed of the complacency that covers it which makes it difficult for Africa to key into the developmental process. This begins with a strategic reconditioning of the African mind by restoring a great deal of confidence and will to rise. The African seem to be bottled and crippled by the belief that the western hegemony has taken away every possibility of development. This erroneous belief is what results in the negative freedom which holds Africa down and denies her the opportunity of development. Bill Bernhard (2011: p. 13) succinctly explains that,

The beginning of development lies in the will to develop. He will is supported by the human ingenuity which may not be equally given but places the individual on a visible plane of globalization.

Bernhard's postulation is as much a clarion call to the re awakening of the African rational system. Here there is need to showcase one's ingenuity primarily through an ontological freedom granted by one's humanness. This will place Africa right on the platform of development in the globalizing world.

\section{Conclusion}

During the course of this work, it is established that freedom is very pertinent for any form of developmental process. This is the African predicament. The African nation seems to lack such freedom both internally and externally, this results in the progressive underdevelopment of African continent. To find the solution to this problem, a lot tinkers stemmed up reactionary attitudes towards asserting the African freedom. Dukor extensively proffers a lot of ideas towards the establishment of the necessary freedom for African development.

Dukor established some basis upon which the assumption of the African freedom is based. These bases were employed in the attempt to draw the attention of Africans to the freedom which pervades her. Apparently, the negative freedom which suffuses the African system seems to blind Africans from development. Thus, this call to positive and responsible freedom becomes very important. In the first place, Africans should rise from her psychologically moribund state, convince themselves of their freedom and ingenuity and therefore make a positive impact in the global development. On the other hand, the western hegemony, which seems to have taken over the freedom of the world, must be corrected. Dukor accepts that the western domination of Africa has been predicated in western prejudice 


\section{A. OKOYE}

and emotional intolerance of the back man. However, the freedom bestowed on the Africans by his humanness and existential goals makes it ethically wrong for the Africans to be enslaved under hammers of western neocolonialism. Indeed, freedom Africa must be projected and promoted for any meaningful development to take place.

\section{REFERENCES}

Abraham, W. (1962). The mind of Africa. London: Weidenfeld and Nicolson.

Afigbo, A. E. (1993). History and responsibility. Keynote Address Delivered at the Meeting of the American Studies Association of Nigeria, University of Nigeria, Nsukka.

Anyanwu, K. C. (2007). Introduction to African Philosophy (4th ed.). Nairobi: Pauline Books.

Bill, B. (2011). Development and the world order.

Blyden, W. (1969). African life and customs (2nd ed.). London: African Publication Society.

Downs, J. (1984). Cultures in crisis. New York: AP Press Ltd.
Dukor, M. (2010). African freedom, the freedom of philosophy. Usa: Lambert Academic Publishing.

Edwin, W. S. (1998). The golden stool. London: Edinburgh.

Fanon, F. (1964). Black skin, white mask. New York: Colliet Books.

Habermas, J. (2003). Theory of communicative action (Vol. 1). Cambridge: Polity Press.

Heidegger, M. (1962). Being and time. Usa: Blackwell Pub. Ltd.

Jahn, J. (1961). Muntu: An outline of Neo-African culture. London: Faber and Faber Ltd.

Killens, O. (1968). Explanation of the back psyche. In A. Adoff (Ed.), Black on black. New York: Macmillan Company.

Okoye, M. (1964). African responses devon. Iifracombe: Arthur H. Stockwell Ltd.

Onyeocha, I. (1997). Africa: The question of identity. Washington DC: CRVP.

Rodney, W. (1972). How Europe underdeveloped Africa. Dar Es Salam: Tanzania Publishing House.

Sartre, J. P. (1974). Existentialism is a humanism (Trans. Bernard Frechtman). London: Methuen Pub. Co.

Swinburne (2003). Ethical grounds of freedom. In J. Baggini (Ed.), What philosophers think. London: Continuum. 